Article

\title{
Solvothermal synthesis and characterization of nanocrystalline vanadium-chromium composite oxides and catalytic ammoxidation of 2,6-dichlorotoluene
}

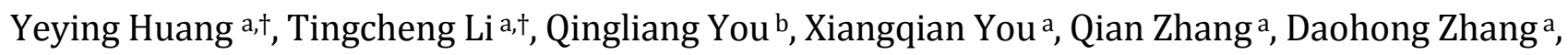 \\ Guangyong Xie ${ }^{\mathrm{a}, *}$ \\ a Key Laboratory of Catalysis and Materials Science of the State Ethnic Affairs Commission \& Ministry of Education, South-Central University for \\ Nationalities, Wuhan 430074, Hubei, China \\ ${ }^{\mathrm{b}}$ Key Laboratory of Optoelectronic Chemical Materials and Devices, Ministry of Education, School of Chemical and Environmental Engineering, Jianghan \\ University, Wuhan 430056, Hubei, China
}

\section{A R T I C L E I N F O}

\section{Article history:}

Received 12 April 2018

Accepted 1 June 2018

Published 5 November 2018

\section{Keywords:}

$\mathrm{CrVO}_{4}$

Nanocrystalline material

Composite oxide

Solvothermal synthesis

Ammoxidation

\begin{abstract}
A B S T R A C T
Vanadium-chromium oxides ( $\mathrm{VCrO}$ ) were usually prepared by high-temperature solid-state reactions; however, mixed phases were frequently produced and the morphology of the products was not well controlled. In this work, we prepared amorphous $\mathrm{VCrO}$ precursors by using $\mathrm{V}_{2} \mathrm{O}_{5}$ and $\mathrm{CrO}_{3}$ and alcohols or mixtures of alcohol and water via solvothermal reaction at $180^{\circ} \mathrm{C}$. The precursors were then calcined under nitrogen at various temperatures. The products were characterized by powder X-ray diffraction, transmission electron microscopy, and X-ray photoelectron spectroscopy. It was revealed that pure-phase nanocrystalline orthorhombic $\mathrm{CrVO}_{4}$ was obtained when methanol or methanol/water was used as the solvothermal medium and the precursor was calcined at $700^{\circ} \mathrm{C}$. The size of the $\mathrm{CrVO}_{4}$ crystals was around $500 \mathrm{~nm}$ when methanol was used, whereas it reduced significantly to less than $50 \mathrm{~nm}$ when a mixture of methanol and water was used. The sizes could be effectively tuned from 10 to $50 \mathrm{~nm}$ by varying the methanol/water volume ratio. To the best of our knowledge, this is the first report on the synthesis of pure-phase $\mathrm{CrVO}_{4}$ nanocrystals. The nano- $\mathrm{CrVO}_{4}$ showed almost the highest catalytic activity for the ammoxidation of 2,6-dichlorotoluene to 2,6-dichlorobenzonitrile among the reported bi-component composite oxides, owing to its smaller particle size, larger specific surface area, and more exposed active centers. (C) 2018, Dalian Institute of Chemical Physics, Chinese Academy of Sciences. Published by Elsevier B.V. All rights reserved.
\end{abstract}

\section{Introduction}

Ammoxidation of alkyl aromatics and heteroaromatics to their corresponding aromatic nitriles has been considered another significant breakthrough in the chemical industry after the ammoxidation of propylene to acrylonitrile, and has attracted a great deal of attention [1-21] because the nitriles are very useful organic intermediates for the preparation of a good number of industrially important chemicals such as aromatic acids, amides, amines and so on, which provide raw materials

\footnotetext{
* Corresponding author. Tel/Fax: +86-27-67842752; E-mail: xiegy@scuec.edu.cn

These authors have contributed equally.

This work was supported by the National Natural Science Foundation of China (21172269), Innovation Group of Hubei Natural Science Foundation (2018CFA023) and Opening Project of Key Laboratory of Optoelectronic Chemical Materials and Devices, Ministry of Education, Jianghan University (JDGD-201809).

DOI: 10.1016/S1872-2067(18)63119-5 | http://www.sciencedirect.com/science/journal/18722067 | Chin. J. Catal., Vol. 39, No. 11, November 2018
} 
for further production of pharmaceuticals, pesticides, pigments, dyes, rubbers, and optoelectronic materials. Gas-phase ammoxidation of 2,6-dichlorotoluene (DCT) to 2,6-dichlorobenzonitrile (DCBN) is of particular importance owing to the high industrial significance of DCBN for manufacturing many effective herbicides, fungicides, and various special kinds of engineering plastics [15-21]. Nevertheless, the realization of this reaction with high conversion and yield remains a challenging task and is much more difficult compared to the ammoxidation of various other alkyl aromatics and heteroaromatics due to steric hindrance of the reacting methyl group by two neighboring bulky chlorine atoms.

Martin et al. [18-21] have used vanadium phosphates (VPO) as catalysts to successfully ammoxidize DCT to DCBN with almost $99 \%$ conversion and $\mathrm{ca} .70 \%$ yield at $400-420{ }^{\circ} \mathrm{C}$. Our group has been committed to developing highly active and selective catalysts and effective strategies for the ammoxidation of methyl aromatics to the corresponding aromatic nitriles [1-5,15-17], and has studied the catalytic performances of silica-supported vanadium-phosphorus oxides $\left(\mathrm{VPO} / \mathrm{SiO}_{2}\right)$ $[15,16]$ and vanadium-chromium oxides $\left(\mathrm{VCrO} / \mathrm{SiO}_{2}\right)$ [17] for the ammoxidation of DCT to DCBN.

Vanadium-chromium composite oxides (VCrO) have been the subject of extensive research because of their use in a wide range of applications such as heterogeneous catalysis [1-9,22,23], gas sensing [24], and energy storage [25,26]. They were traditionally prepared by high-temperature solid-state reactions between pure oxide components. Depending on the reaction conditions, various phases such as $\mathrm{CrVO}_{4}$ [27], $\mathrm{Cr}\left(\mathrm{VO}_{3}\right)_{3}$ [28], $\mathrm{Cr}_{4}\left(\mathrm{~V}_{2} \mathrm{O}_{7}\right)_{3}$ [29], and $\mathrm{Cr}_{2} \mathrm{~V}_{4} \mathrm{O}_{13}$ [30] may occur. Among these, $\mathrm{CrVO}_{4}$ has been widely used as an oxidation catalyst in some important industrial reactions, including oxidation of benzene to maleic anhydride or methanol to formaldehyde and the ammoxidation of aromatic compounds $[1-9,14,31] . \mathrm{CrVO}_{4}$ has three different crystal structures, namely orthorhombic, monoclinic, and tetragonal [32]. Orthorhombic $\mathrm{CrVO}_{4}$ has been obtained by heating an amorphous precursor, $\mathrm{CrVO}_{4} \cdot 3 \mathrm{H}_{2} \mathrm{O}$, at $450{ }^{\circ} \mathrm{C}$, whose precursor was synthesized by the reaction of solutions of ammonium vanadate $\left(\mathrm{NH}_{4} \mathrm{VO}_{3}\right)$ and chromium nitrate $\left[\mathrm{Cr}\left(\mathrm{NO}_{3}\right)_{3} \cdot 9 \mathrm{H}_{2} \mathrm{O}\right.$ ] [33]. It could also be prepared by grinding a mixture of hydrous amorphous chromium oxide and vanadium oxide [34]. However, mixed phases of VCrO complexes were produced in these cases and the particle sizes were not well controlled. When used in an oxidation or ammoxidation reaction, a high temperature was required and resulted in the over-oxidation of the raw material as well as the deposition of carbon and loss of activity over time [27].

Recently, Huang et al. [6] reported the synthesis of sphere-like amorphous VCrO particles several micrometers in size and studied their catalytic performance for the ammoxidation of dichlorotoluenes. It was found that the size and morphology of the solid catalysts could influence the catalytic behaviors significantly. However, to the best of our knowledge, no literature about nano-sized crystalline $\mathrm{CrVO}_{4}$ has been reported. Here, we present a facile solvothermal route to synthesize pure-phase nanocrystalline orthorhombic $\mathrm{CrVO}_{4}$ for the first time, which exhibited excellent catalytic performance for the ammoxidation of DCT with high conversion and yield at a relatively low temperature.

\section{Experimental}

\subsection{Materials and procedure}

All reagents used in the experiments were of analytical grade and purchased locally. In a typical synthesis, (1) $0.01 \mathrm{~mol}$ (1.82 g) of $\mathrm{V}_{2} \mathrm{O}_{5}$ powder, $0.02 \mathrm{~mol}$ ( $2.0 \mathrm{~g}$ ) of $\mathrm{CrO}_{3}$ powder, and $80 \mathrm{~mL}$ methanol were successively added to a $100-\mathrm{mL}$ Teflon-lined autoclave, stirred and mixed thoroughly, and then heated at $180{ }^{\circ} \mathrm{C}$ for $24 \mathrm{~h}$. After cooling to room temperature, the dark-green mixture was separated by filtration and washed with distilled water and absolute ethanol several times. The residue was vacuum dried at $60^{\circ} \mathrm{C}$ for $5 \mathrm{~h}$ to afford a precursor. Appropriate amounts of the precursors were then placed in quartz boats and calcined in a tube furnace under nitrogen atmosphere (more than 99\% pure nitrogen was introduced) for $2 \mathrm{~h}$ at 200, 300, 400, 500, 600, and $700{ }^{\circ} \mathrm{C}$, respectively. (2) Methanol was replaced with ethanol, isopropanol, or methanol/water $(1: 1 \mathrm{~V} / \mathrm{V})$ and the above procedure was repeated and the precursor was calcined at $400,500,600$, and $700{ }^{\circ} \mathrm{C}$, respectively.

\subsection{Characterization}

X-ray powder diffraction (XRD) was performed on a Bruker D8 X-ray diffractometer with $\mathrm{Cu} K_{\alpha}$ radiation, $\lambda=0.154 \mathrm{~nm}$. X-ray photoelectron spectroscopy (XPS) was conducted on a VG Multilab 2000 X XPS spectrometer. The morphology of the powder particles was examined using a TECNAI G2 20 S-TWIN transmission electron microscope (TEM).

\subsection{Ammoxidation of 2,6-dichlorotoluene}

The catalytic reactions were conducted in a fixed-bed micro-reactor equipped with a 30-mm inner diameter glass tube loaded with $10 \mathrm{~g}$ of nanocrystalline $\mathrm{CrVO}_{4}$. DCT was injected into the vaporizer by a micro-injection pump, and the vaporized reactant was then mixed with ammonia and air and fed into the reactor. The outlet stream was cooled and the products were condensed to solid in a condensing apparatus. Test runs were carried out at different conditions by varying the temperature, space velocity of the reactant, and the molar ratios of ammonia and air to DCT. The product steam was collected every 30 min after attaining steady state conditions and then analyzed off-line by gas chromatograph. The chemical reaction of DCBN synthesis by the ammoxidation of DCT is shown in Scheme 1.

\section{Results and discussion}

\subsection{Synthesis of the $\mathrm{V}-\mathrm{Cr}-\mathrm{O}$ precursor}

The precursor prepared by the solvothermal reaction of 


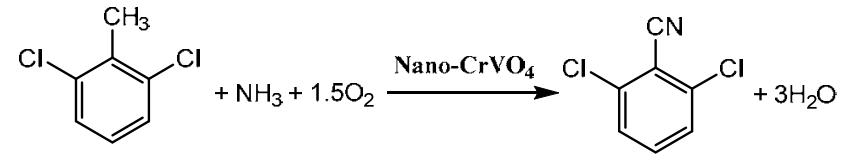

Scheme 1. Preparation of DCBN by ammoxidation of DCT using nano-VCrO catalyst.

$\mathrm{V}_{2} \mathrm{O}_{5}, \mathrm{CrO}_{3}$, and methanol at $180^{\circ} \mathrm{C}$ for $24 \mathrm{~h}$ was characterized by XRD. There were no diffraction peaks in the XRD patterns, suggesting that no crystal phases were formed at this stage. Replacing methanol with ethanol or isopropanol, extending the reaction time to $48 \mathrm{~h}$, or raising the solvothermal temperature to $200{ }^{\circ} \mathrm{C}$ did not alter the amorphousness of the precursors (powder XRD patterns not shown).

\subsection{Production of $\mathrm{V}-\mathrm{Cr}-\mathrm{O}$}

The methanol-reduced vanadium-chromium oxide precursor was placed in quartz boats and calcined in a tube furnace under nitrogen atmosphere for $2 \mathrm{~h}$ at 200, 300, 400, 500, 600, and $700{ }^{\circ} \mathrm{C}$, and their XRD patterns are shown in Fig. 1. Diffraction peaks began to appear at $400{ }^{\circ} \mathrm{C}$ (Fig. 1(3)), indicating the formation of crystal phases. At $500{ }^{\circ} \mathrm{C}$, sharp peaks corresponding to $\mathrm{Cr}_{2} \mathrm{~V}_{4} \mathrm{O}_{13}$ (Fig. 1(4), black dot indicated) and tetragonal $\mathrm{CrVO}_{4}$ (Fig. 1(4), star indicated) could be distinguished. At $600^{\circ} \mathrm{C}$, significant amounts of orthorhombic $\mathrm{CrVO}_{4}$ (Fig. 1(5), black triangle indicated) were produced, and a small amount of tetragonal $\mathrm{CrVO}_{4}$ phase was still present. The assignment of these peaks was referred to PDF cards PDF\#51-0445, PDF\#15-0296, and PDF\#38-1376, respectively. At $700{ }^{\circ} \mathrm{C}$, however, only well-resolved orthorhombic $\mathrm{CrVO}_{4}$ peaks were observed (Fig. 1(6)), suggesting the production of pure-phase crystalline orthorhombic $\mathrm{CrVO}_{4}$. The diffraction pattern well matches the PDF card (\#38-1376) of orthorhombic $\mathrm{CrVO}_{4}$ and the peaks were indexed accordingly.

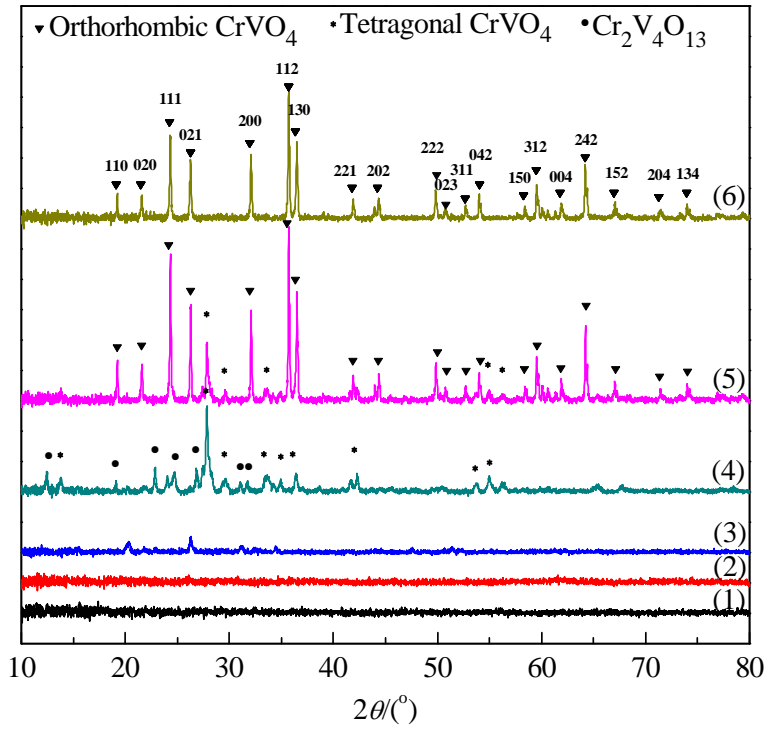

Fig. 1. XRD patterns of $\mathrm{V}-\mathrm{Cr}-\mathrm{O}$ samples using methanol as solvothermal medium and calcined at various temperatures. (1) $200{ }^{\circ} \mathrm{C}$, (2) $300{ }^{\circ} \mathrm{C}$, (3) $400{ }^{\circ} \mathrm{C}$, (4) $500{ }^{\circ} \mathrm{C},(5) 600^{\circ} \mathrm{C},(6) 700^{\circ} \mathrm{C}$.
Precursors using ethanol and isopropanol as solvothermal media were subsequently produced and calcined at 400,500 , 600 , and $700{ }^{\circ} \mathrm{C}$. Crystal phases began to appear at $400{ }^{\circ} \mathrm{C}$, and at $700{ }^{\circ} \mathrm{C}$, the major products were still orthorhombic $\mathrm{CrVO}_{4}$; however, a small amount of another phase, probably $\mathrm{CrVO}_{3}$, still remained (Fig. 2). In contrast, replacing methanol with mixtures of methanol and distilled water (volume ratio of 1:1) produced pure-phase orthorhombic $\mathrm{CrVO}_{4}$ (Fig. 2(3)).

\subsection{Morphology of the precursor and the calcined powder}

The amorphous state of the precursor and the crystalline nature of the orthorhombic $\mathrm{CrVO}_{4}$ powder were substantiated by TEM measurement. Fig. 3(a), (b), (c) and (d) show the TEM micrographs of the methanol-reduced precursor and calcined powders, respectively. The TEM image of the precursor (Fig. 3(a)) is typical of an amorphous solid, with a particle size of around $20 \mathrm{~nm}$. When calcined at $500{ }^{\circ} \mathrm{C}$, regularly shaped rod-like and cube-like nanocrystals around $100 \mathrm{~nm}$ in size were formed (Fig. 3(b)). Raising the calcination temperature to 600 ${ }^{\circ} \mathrm{C}$ and $700^{\circ} \mathrm{C}$ led to further growth of the crystallites to about 200 and $500 \mathrm{~nm}$, respectively (Fig. 3(c) and (d)).

The addition of water to methanol produced well-crystalline $\mathrm{CrVO}_{4}$, and greatly reduced the size of the $\mathrm{CrVO}_{4}$ nanocrystals. Moreover, the size could be effectively tuned by the methanol/water ratio (Fig. 3(e)-(h)). When a 10:1 ratio was used, well-crystalline particles with $\sim 50$-nm diameter were produced (Fig. 3(e)). The particle sizes further decreased to $\sim 30$, $\sim 20$, and $\sim 10 \mathrm{~nm}$, respectively, when the volume ratios decreased to 5:1, 1:1, and 1:5 (Fig. 3(f), (g), and (h)). The addition of water to the hydrothermal medium is expected to decrease the concentration of methanol as well as its reducing ability; thus, the growth of crystals may be impeded, resulting in the production of finer nanoparticles. Ethanol or mixtures of ethanol/water as a reducing reagent to synthesize transition metal oxides have occasionally been reported, and it was found that the ratio of ethanol $/ \mathrm{H}_{2} \mathrm{O}$ had significant effects on the mor-

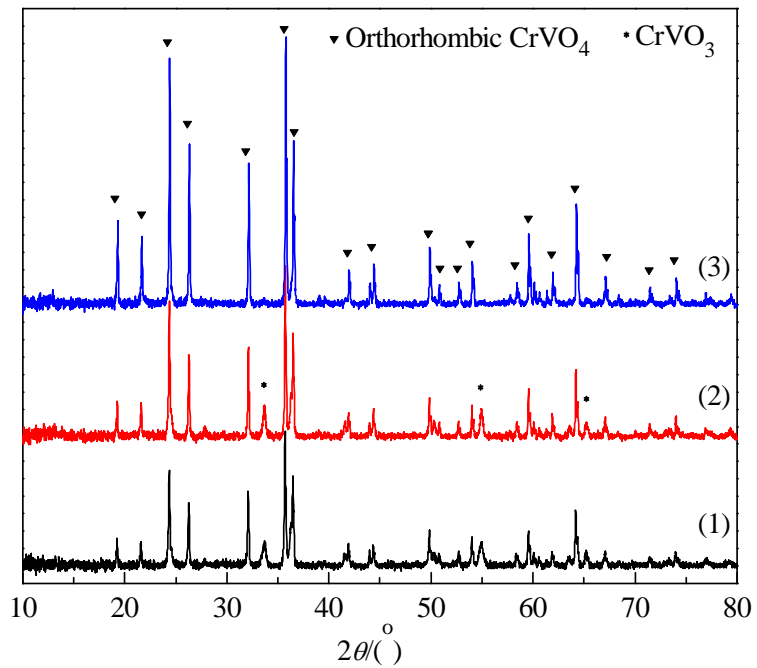

Fig. 2. XRD patterns of $\mathrm{V}-\mathrm{Cr}-\mathrm{O}$ samples using (1) ethanol, (2) isopropanol, and (3) methanol/water $(1: 1 \mathrm{~V} / \mathrm{V})$ as solvothermal media and calcined at $700{ }^{\circ} \mathrm{C}$. 

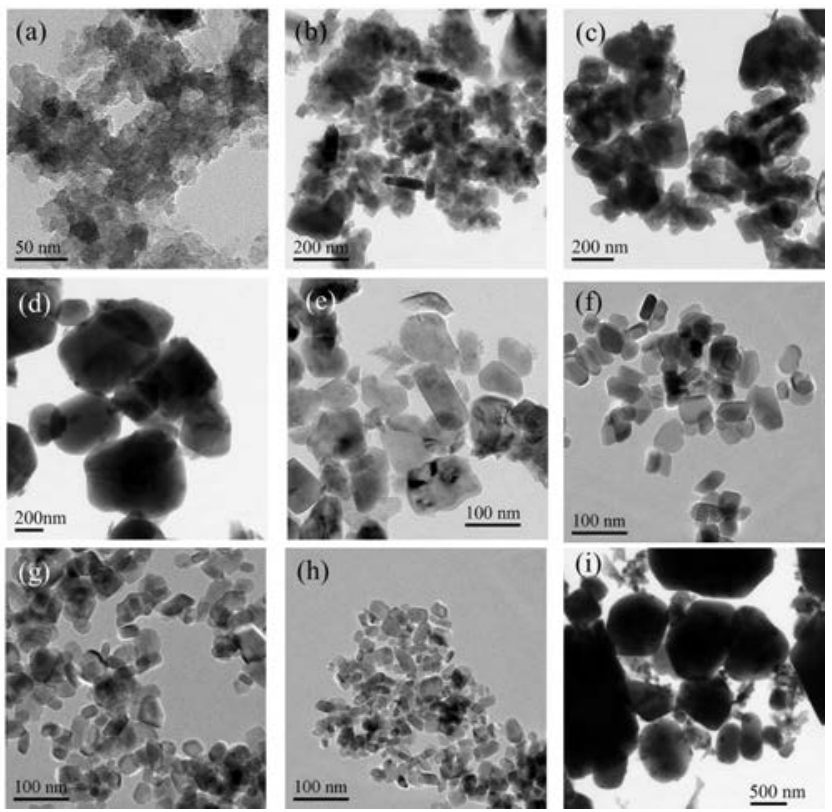

Fig. 3. TEM micrographs of the precursor and calcined powders. (a) Precursor, (b) $500{ }^{\circ} \mathrm{C}$, (c) $600^{\circ} \mathrm{C}$, (d)-(i) $700^{\circ} \mathrm{C}$. (a)-(d) were produced using methanol; (e)-(h) were produced using methanol/water: (e) 10:1 $(V / V)$, (f) 5:1 (V/V), (g) 1:1 (V/V), (h) 1:5 (V/V); (i) was produced using $\mathrm{H}_{2} \mathrm{C}_{2} \mathrm{O}_{4}$ solution.

phology and composition of the as-obtained products [35].

In comparison, calcination of the respective oxalates, i.e., using $\mathrm{V}_{2} \mathrm{O}_{5}, \mathrm{CrO}_{3}$, and $\mathrm{H}_{2} \mathrm{C}_{2} \mathrm{O}_{4}$ solutions as the starting materials by a similar hydrothermal approach produced micrometer-sized crystals $(\sim 1 \mu \mathrm{m}$ in diameter, Fig. 3(i)).

\subsection{XPS study of $\mathrm{CrVO}_{4}$ nanocrystals}

The chemical states of the elements in the precursor and V-Cr-O complexes calcined at various temperatures were studied by XPS. The spectra were taken on a VG Multilab 2000 X XPS spectrometer and calibrated using the C $1 s$ peak 284.6 $\mathrm{eV}$ ) arising from carbon contamination. As shown in the survey spectrum (Fig. 4), the $\mathrm{CrVO}_{4}$ nanocrystal showed peaks at about 586, 577, 530, 517, and $285 \mathrm{eV}$ corresponding to $\mathrm{Cr} 2 p_{1 / 2}$,

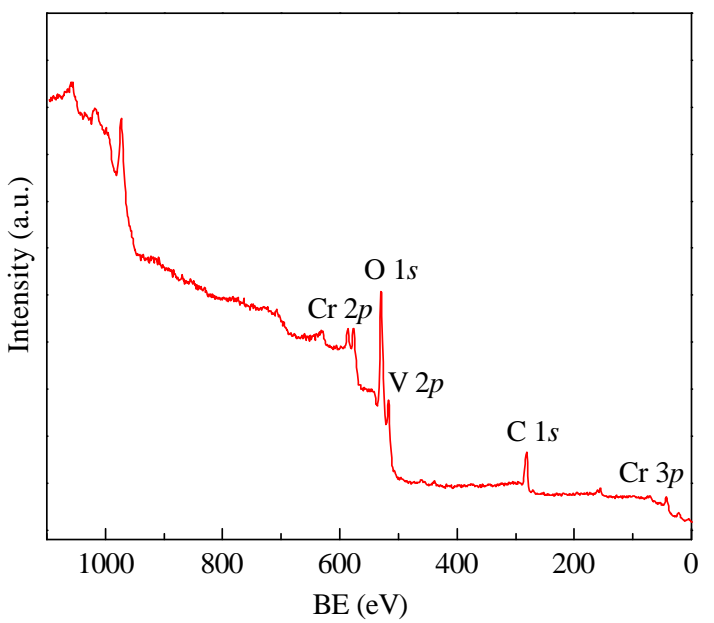

Fig. 4. XPS survey spectrum of $\mathrm{CrVO}_{4}$ nanocrystal (calcined at $700{ }^{\circ} \mathrm{C}$ ).

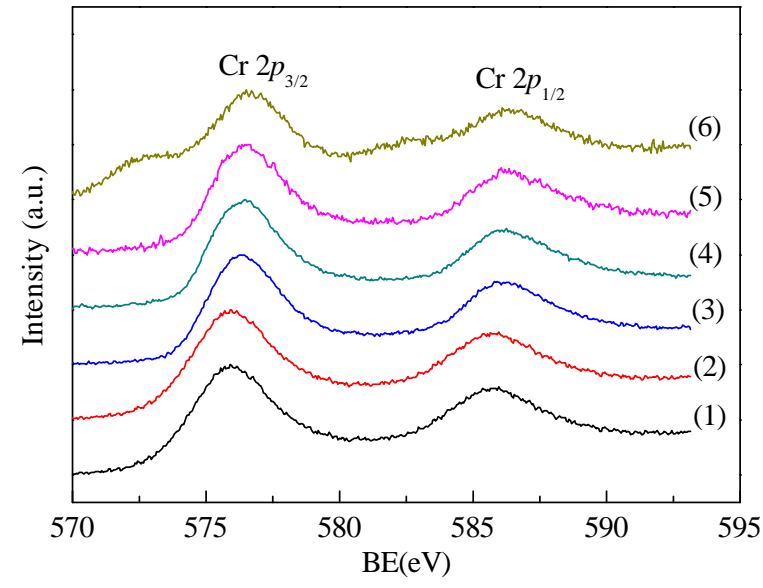

Fig. 5. Normalized XPS spectra ( $\mathrm{Cr} 2 p$ ) of the precursor (1) and $\mathrm{V}-\mathrm{Cr}-\mathrm{O}$ complexes calcined at 300 (2), $400(3), 500$ (4), 600 (5), and $700{ }^{\circ} \mathrm{C}(6)$.

$\mathrm{Cr} 2 p_{3 / 2}, \mathrm{O} 1 s, \mathrm{~V} 2 p_{3 / 2}$, and C $1 s$, respectively.

The high-resolution spectra of the $\mathrm{Cr}$ and $\mathrm{V}+\mathrm{O}$ regions are presented in Figs. 5 and 6, respectively. The data were processed using the XPS Peak41 package as shown in Fig. 7, with the detailed results summarized in Table 1 . The fittings of $\mathrm{V} 2 p$ are combined with the $01 s$ region as G. Silversmit et al. [36] suggested because this fit model is significantly better than fitting without the $01 s$ region included. The binding energies (BE) of $\mathrm{Cr} 2 p_{1 / 2}$ and $\mathrm{Cr} 2 p_{3 / 2}$ showed no appreciable differences and appeared at 586.2 and $576.6 \mathrm{eV}$, respectively, well consistent with the $\mathrm{Cr}^{3+}$ oxidation state $[37,38]$. The $\mathrm{V} 2 p_{1 / 2}$ and $\mathrm{V}$ $2 p_{3 / 2}$ signals were observed at $\sim 522$ and $\sim 516 \mathrm{eV}$ initially and shifted to 526.5 and $516.9 \mathrm{eV}$, respectively, when the calcination temperature was raised to $700{ }^{\circ} \mathrm{C}$. The results suggested that chromium was reduced to $\mathrm{Cr}^{3+}$ after the solvothermal reaction, but vanadium did not fully convert to $\mathrm{V}^{5+}$ oxidation state until calcination at $700{ }^{\circ} \mathrm{C}$ [36-38].

\subsection{Possible reaction mechanism}

The possible solvothermal reaction mechanism is shown in

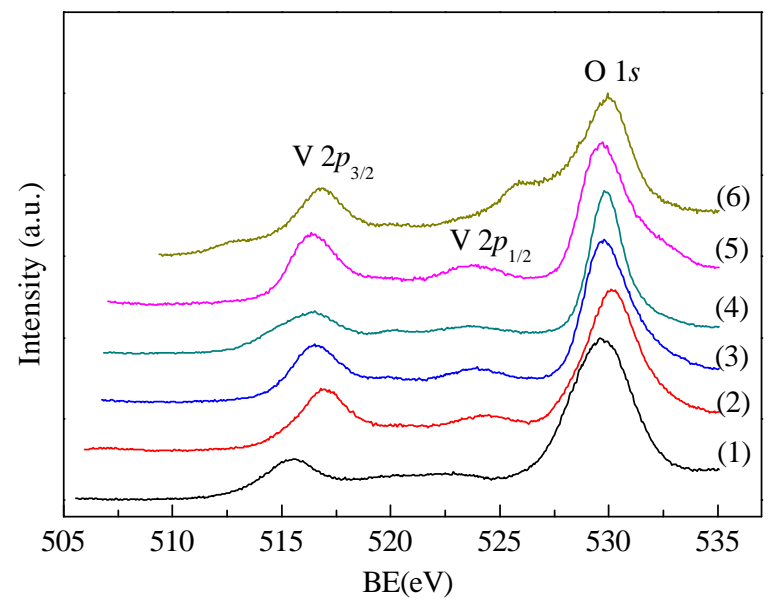

Fig. 6. Normalized XPS spectra (V $2 p$ and $01 s$ ) of the precursor (1) and $\mathrm{V}-\mathrm{Cr}-\mathrm{O}$ complexes calcined at 300 (2), 400 (3), 500 (4), 600 (5), and $700{ }^{\circ} \mathrm{C}(6)$ 

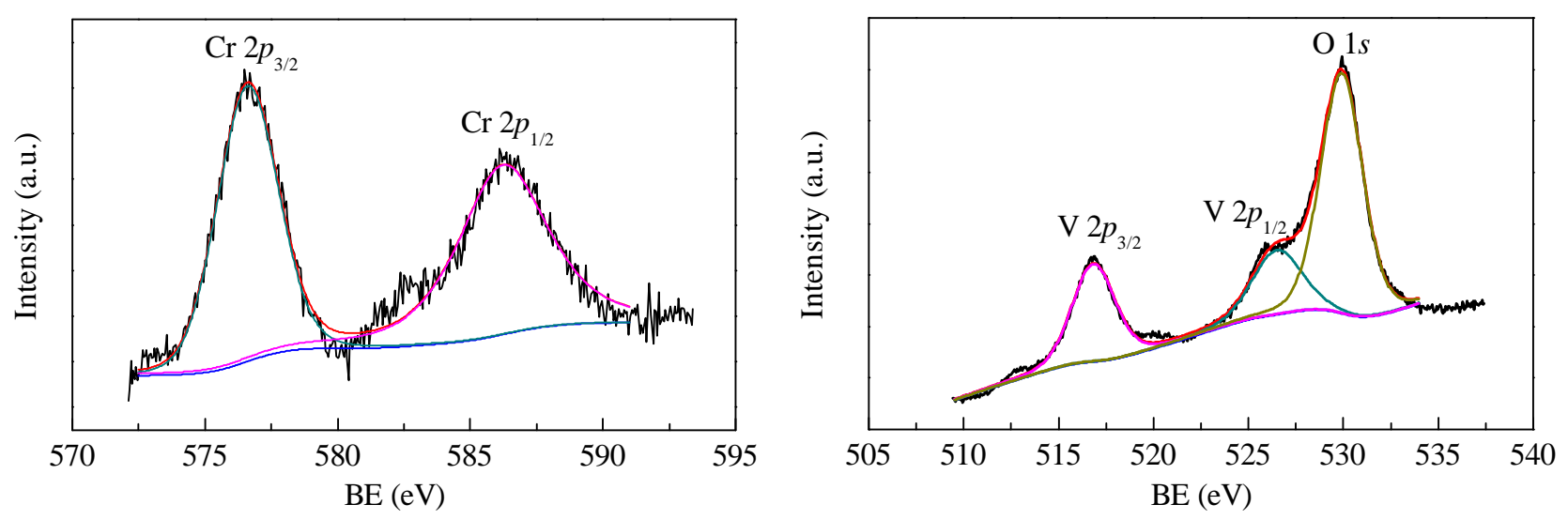

Fig. 7. High-resolution XPS spectra of $\mathrm{Cr} 2 p, 01 s$, and V $2 p$ regions.

Scheme 2. Methanol reduced the chromium from sexavalent to trivalent state to form nanocrystalline orthorhombic $\mathrm{CrVO}_{4}$ with vanadium oxides.

\subsection{Ammoxidation of 2,6-dichlorotoluene}

DCBN is an important fine chemical and can be prepared by the gas-phase ammoxidation of DCT. However, only a few papers were dedicated to this route and low yields were often obtained due to the low reactivity of the methyl group from the steric hindrance of the two neighboring bulky and electron-withdrawing chlorine atoms. Most of the catalysts for the ammoxidation of DCT were focused on VPO [15,16,18-21]. In this work, nanocrystalline $\mathrm{CrVO}_{4}$ produced by solvothermal reaction was found to have interesting catalytic performance for the ammoxidation of DCT to DCBN. The findings along with some typical literature results are listed in Table 2.

From Table 2, it was found that the composition and structure of the catalysts could exert great influence on the catalytic behavior. For example, unsupported VPO catalysts showed weak catalytic activity toward ammoxidation of DCT even at very high temperatures (Entry 1 and 3, Table 2), while the activity could be considerably improved as the VPO catalysts were loaded on supports such as $\mathrm{SiO}_{2}, \mathrm{Al}_{2} \mathrm{O}_{3}$, or $\mathrm{TiO}_{2}$ (Entry 2, 4, and 5, Table 2), probably owing to the larger specific surface areas and more exposed active centers. Furthermore, some micro- or nano-sized composite oxides may exist on the supports.

Table 1

$\mathrm{BE}$ of $\mathrm{V} 2 p, \mathrm{Cr} 2 p$, and $\mathrm{O} 1 s$ and the fitting parameters.

\begin{tabular}{lcccccc}
\hline \multirow{2}{*}{ Core line } & \multirow{2}{*}{ Precursor } & \multicolumn{5}{c}{ Calcined V-Cr-O Powders } \\
\cline { 3 - 7 } & & $300{ }^{\circ} \mathrm{C}$ & $400{ }^{\circ} \mathrm{C}$ & $500{ }^{\circ} \mathrm{C}$ & $600{ }^{\circ} \mathrm{C}$ & $700{ }^{\circ} \mathrm{C}$ \\
\hline $\mathrm{V} 2 p_{3 / 2}$ & 516.2 & 516.8 & 516.4 & 515.9 & 516.3 & 516.9 \\
$\mathrm{~V} 2 p_{1 / 2}$ & 522.6 & 524.2 & 523.7 & 523.1 & 523.3 & 526.5 \\
$\mathrm{O} 1 s$ & 530.6 & 530.1 & 530.0 & 529.9 & 529.6 & 529.9 \\
$\mathrm{Cr} 2 p_{3 / 2}$ & 576.5 & 576.8 & 576.4 & 576.5 & 576.5 & 576.6 \\
$\mathrm{Cr} 2 p_{1 / 2}$ & 586.2 & 586.6 & 586.1 & 586.2 & 586.3 & 586.3 \\
\hline
\end{tabular}

$$
\mathrm{V}_{2} \mathrm{O}_{5}+2 \mathrm{CrO}_{3}+3 \mathrm{CH}_{3} \mathrm{OH} \stackrel{\text { Solvothermal reaction }}{\longrightarrow} 2 \mathrm{CrVO}_{4}+3 \mathrm{HCHO}+3 \mathrm{H}_{2} \mathrm{O}
$$

Scheme 2. Possible solvothermal reaction mechanism.
The nano- $\mathrm{CrVO}_{4}$ exhibited excellent catalytic activity for the ammoxidation of DCT even at relatively low temperatures. At $335{ }^{\circ} \mathrm{C}$, the conversion of DCT is $84 \%$, and the yield and selectivity of DCBN were $75 \%$ and $89 \%$, respectively (Entry 7 , Table 2). The nano- $\mathrm{CrVO}_{4}$ catalyst exhibited (5-6)\% higher conversion and yield with similar selectivity compared with those of the micro-sized $\mathrm{V}-\mathrm{Cr}-\mathrm{O}$ catalysts reported by Huang's group (Entry 6, Table 2). When the temperature was raised to $390^{\circ} \mathrm{C}$, the conversion of DCT and the yield of DCBN increased to $99 \%$ and $81 \%$, respectively (Entry 8, Table 2), which was almost the highest activity for ammoxidizing DCT to DCBN among the reported bi-component composite oxides. In contrast, the micro- $\mathrm{CrVO}_{4}$ that we prepared by solvothermal reaction using $\mathrm{H}_{2} \mathrm{C}_{2} \mathrm{O}_{4}$ solution as a reducing agent showed a similar catalytic activity compared to the micrometer-sized $\mathrm{V}-\mathrm{Cr}-\mathrm{O}$ reported by Huang's group (Entry 9 vs. 6, Table 2). The excellent catalytic performances of the nanostructured VCrO were thus attributable to the very small particle sizes, which led to high surface

Table 2

Catalytic performances of different catalysts for ammoxidation of DCT a.

\begin{tabular}{|c|c|c|c|c|c|c|}
\hline Entry & Catalyst & $\begin{array}{c}T \\
\left({ }^{\circ} \mathrm{C}\right)\end{array}$ & $\begin{array}{c}\text { Conver- } \\
\text { sion } \\
(\%)\end{array}$ & $\begin{array}{c}\text { Yield } \\
(\%)\end{array}$ & $\begin{array}{l}\text { Selec- } \\
\text { tivity } \\
(\%) \\
\end{array}$ & Ref. \\
\hline 1 & $\left(\mathrm{NH}_{4}\right)_{2}\left[(\mathrm{VO})_{3}\left(\mathrm{P}_{2} \mathrm{O}_{7}\right)_{2}\right]$ & 420 & 50 & 18 & 36 & [39] \\
\hline 2 & $\mathrm{VPO} / \gamma-\mathrm{Al}_{2} \mathrm{O}_{3}$ & 400 & 99 & 71 & 72 & [18] \\
\hline 3 & Bulk VPO & 440 & 92 & 55 & 60 & [18] \\
\hline 4 & $\mathrm{VPO} / \mathrm{SiO}_{2}$ & 380 & 87 & 57 & 66 & {$[15]$} \\
\hline 5 & $\mathrm{VPO} / \mathrm{SiO}_{2}$ & 400 & 90 & 57 & 63 & {$[16]$} \\
\hline 6 & $\mathrm{~V}-\mathrm{Cr}-\mathrm{O}$ & 335 & 78 & 70 & 90 & [6] \\
\hline 7 & $\mathrm{Nano}_{-} \mathrm{CrVO}_{4}$ & 335 & 84 & 75 & 89 & This work ${ }^{b}$ \\
\hline 8 & $\mathrm{Nano}_{-} \mathrm{CrVO}_{4}$ & 390 & 99 & 81 & 82 & This work ${ }^{b}$ \\
\hline 9 & $\mathrm{Micro}_{-} \mathrm{CrVO}_{4}$ & 335 & 77 & 68 & 88 & This work ${ }^{\mathrm{c}}$ \\
\hline 10 & Micro-CrVO 4 & 390 & 92 & 73 & 79 & This work ${ }^{\mathrm{c}}$ \\
\hline
\end{tabular}

a The catalytic performance as characterized by conversion, yield, and selectivity. The conditions of the ammoxidation reactions were as follows: 300 space velocity (SV, the volume of a gas reactant passed through a unit volume of catalyst in unit time, $\left.\mathrm{h}^{-1}\right), n($ Air $) / n($ DCT $)=30$, $n\left(\mathrm{NH}_{3}\right) / n(\mathrm{DCT})=9$.

b $\mathrm{Nano}_{-} \mathrm{CrVO}_{4}$ was produced using 1:1 methanol/water mixture and then calcined at $700^{\circ} \mathrm{C}$.

${ }^{c}$ Micro- $\mathrm{CrVO}_{4}$ was prepared using $\mathrm{H}_{2} \mathrm{C}_{2} \mathrm{O}_{4}$ as a reducing agent and then calcined at $700^{\circ} \mathrm{C}$. 
areas and exposed a large amount of active centers.

\section{Conclusions}

Pure-phase nanocrystalline orthorhombic $\mathrm{CrVO}_{4}$ was obtained through calcination of an amorphous precursor, which was produced from the solvothermal reaction using $\mathrm{V}_{2} \mathrm{O}_{5}$ and $\mathrm{CrO}_{3}$ as raw materials and either methanol or mixtures of methanol and water as the reducing agent. When using mixtures of methanol and water, $\mathrm{CrVO}_{4}$ crystals with much smaller size were produced and the size could be effectively tuned from 10 to $50 \mathrm{~nm}$ by changing the methanol/water volume ratio. The nano- $\mathrm{CrVO}_{4}$ could catalyze the ammoxidation of DCT to produce DCBN with high catalytic activity at relatively low temperatures owing to its very small particle sizes and large specific surface areas.

\section{References}

[1] G. Y. Xie, Q. Zheng, C. Huang, Y. Y. Chen, Indian J. Chem. A, 2002, 41, 963-966.

[2] G. Y. Xie, Q. Zheng, C. Huang, Y. Y. Chen, Synth. Commun., 2003, 33, 1103-1107.

[3] G. Y. Xie, A. Q. Zhang, C. Huang, Res. Chem. Intermed., 2010, 36, 969-973.

[4] G. Y. Xie, A. Q. Zhang, Synth. Commun., 2012, 42, 375-379.

[5] G. Y. Xie, A. Q. Zhang, Bulg. Chem. Commun., 2012, 44, 310-313.

[6] L. L. Xu, Y. F. Zhang, Y. Deng, Y. L. Zhong, S. B. Mo, G. Z. Cheng, C. Huang, Mater. Res. Bull., 2013, 48, 3620-3624.
[7] F. Jiang, W. Xu, L. Niu, G. M. Xiao, Catal. Lett., 2013, 143, 1200-1206.

[8] F. Jiang, S. C. Deng, L. Niu, G. M. Xiao, Chin. J. Catal., 2013, 34, 1833-1838.

[9] F. Jiang, R. P. Wei, L. J. Gao, G. M. Xiao, L. Niu, Res. Chem. Intermed., 2013, 39, 1353-1361.

[10] A. Martin, V. N. Kalevaru, ChemCatChem, 2010, 2, 1504-1522.

[11] N. R. Shiju, V. V. Guliants. Appl. Catal. A, 2009, 356, 1-17.

[12] B. Lücke, K. V. Narayana, A. Martin, K. Jähnisch. Adv. Synth. Catal., 2004, 346, $1407-1424$.

[13] A. Martin, B. Lücke, Catal. Today, 2000, 57, 61-70.

[14] N. Dhachapally, V. N. Kalevaru, A. Brückner, A. Martin, Appl. Catal. A, 2012, 443-444, 111-118.

[15] G. Y. Xie, C. Huang, Indian J. Chem. Technol., 2007, 14, 371-375.

[16] C. Huang, Q. Zheng, G. Y. Xie, C. W. Xu, Q. Y. Han, Y. Y. Chen, Chin. J. Catal., 1999, 20, 679-680.

[17] Q. Zheng, C. Huang, G. Y. Xie, C. W. Xu, Y. Y. Chen, Synth. Commun., 1999, 29, 2349-2353.

[18] V. N. Kalevaru, B. Lücke, A. Martin, Catal. Today, 2009, 142, 158-164.

[19] A. Martin, V. N. Kalevaru, Q. Smejkal, Catal. Today, 2010, 157, 275-279.

[20] N. Dropka, Q. Smejkal, V. N. Kalevaru, A. Martin, Appl. Catal. A, 2008, 349, 125-132.

[21] N. Dropka, V. N. Kalevaru, A. Martin, D. Linke, B. Lücke, J. Catal., 2006, 240, 8-17.

[22] T. Uematsu, Y. Ogasawara, K. Suzuki, K. Yamaguchi, N. Mizuno, Catal. Sci. Technol., 2017, 7, 1912-1920.

[23] O. Pozdnyakova, E. Kuzmann, L. Szirtes, Solid State Ionics, 2003, 161,301-307.

[24] Z. J. Zhang, Y. V. Kaneti, X. C. Jiang, A. B. Yu, Sensors Actuators B,

\section{Graphical Abstract}

Chin. J. Catal., 2018, 39: 1814-1820 doi: 10.1016/S1872-2067(18)63119-5

\section{Solvothermal synthesis and characterization of nanocrystalline vanadium-chromium composite oxides and catalytic} ammoxidation of 2,6-dichlorotoluene

Yeying Huang, Tingcheng Li, Qingliang You, Xiangqian You, Qian Zhang, Daohong Zhang, Guangyong Xie* South-Central University for Nationalities; Jianghan University

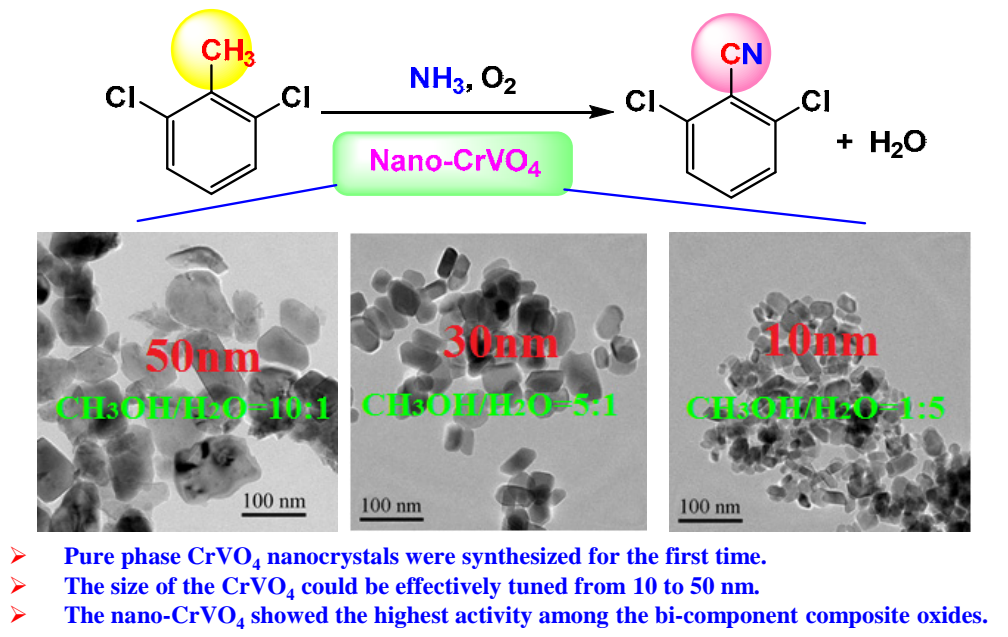

Nano- $\mathrm{CrVO}_{4}$ was obtained for the first time through solvothermal reaction of $\mathrm{V}_{2} \mathrm{O}_{5}$ and $\mathrm{CrO}_{3}$ in either methanol or methanol/water mixtures at $180^{\circ} \mathrm{C}$ to prepare the precursor followed by calcination at $700{ }^{\circ} \mathrm{C}$, which showed almost the highest catalytic activity among the bi-component composite oxides reported for the ammoxidation of 2,6-dichlorotoluene to 2,6-dichlorobenzonitrile. 
2014, 202, 803-809.

[25] D. McNulty, D. N. Buckley, C. O'Dwyer, J. Power Sources, 2014, 267, 831-873.

[26] P. Soudan, J. P. Pereira-Ramos, J. Farcy, G. Gregoire, N. Baffier, Solid State Ionics, 2000, 135, 291-295.

[27] M. Touboul, K. Melgite, J. Mater. Chem., 1995, 5, 147-150.

[28] J. Amiel, D. Olivier, M. Dessolin, C. R. Hebd. Seances Acad. Sci., 1967, 264, 1045-1048.

[29] D. Olivier, P. Rabette, C. R. Hebd. Seances Acad. Sci., 1967, 265, 1451-1454.

[30] S. J. Patwe, S. N. Achary, J. Manjanna, R. M. Kadam, H. G. Salunke, A. K. Tyagi, J. Solid State Chem., 2010, 183, 2770-2778.

[31] A. Chieregato, J. M. Lopez Nieto, F. Cavani, Coord. Chem. Rev., 2015, 301-302, 3-23.
[32] E. J. Baran, J. Mater. Sci., 1998, 33, 2479-2497.

[33] M. Touboul, A. Popot, J. Therm. Anal, 1986, 31, 117-124.

[34] D. Olivier, B. Combe, C. R. Hebd. Seances Acad. Sci. Ser. C, 1968, 267, 877-880.

[35] Y. F. Zhang, X. H. Liu, G. Y. Xie, L. Yu, S. P. Yi, M. J. Hu, C. Huang, Mater. Sci. Eng. B, 2010, 175, 164-171.

[36] G. Silversmit, D. Depla, H. Poelman, G. B. Marin, R. De Gryse. J. Electron Spectrosc. Relat. Phenom., 2004, 135, 167-175.

[37] J. F. Moulder, W. F. Stickle, P. E. Sobol, K. D. Bomben, Handbook of $X$-ray Photoelectron Spectroscopy, Perkin-Elmer Corporation, 1992.

[38] A. Maetaki, M. Yamamoto, H. Matsumoto, K. Kishi, Surf. Sci., 2000, $445,80-88$.

[39] A. Martin, B. Lücke, G.U. Wolf, M. Meisel, Catal. Lett., 1995, 33, 349-355.

\title{
纳米钒铬复合氧化物的溶剂热合成、表征及催化2,6-二氯甲苯氨氧化反应
}

\author{
黄业迎 ${ }^{\mathrm{a}, \dagger}$, 李廷成 ${ }^{\mathrm{a}, \dagger}$, 尤庆亮 ${ }^{\mathrm{b}}$, 游向前 ${ }^{\mathrm{a}}$, 张 倩 ${ }^{\mathrm{a}}$, 张道洪 ${ }^{\mathrm{a}}$, 谢光勇, ${ }^{\mathrm{a}}{ }^{*}$ \\ a 中南民族大学催化材料科学国家民委-教育部重点实验室, 湖北武汉 430074

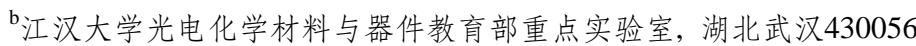

\begin{abstract}
摘要: 甲基芳烃气相氨氧化反应制备对应的芳香腈被认为是丙烯氨氧化制备丙烯腈之后化工领域又一重大进展, 芳香腈 是重要的精细化学品, 广泛应用于医药、农药、颜料、染料、橡胶、光电材料等领域. 其中2,6-二氯甲苯氨氧化反应制备 2,6-二氯苯腈是特别重要的反应, 2,6-二氯苯腈工业上可用于制备高效除草剂、杀菌剂及各种特种工程塑料; 然而相较于其 它的甲基芳烃, 2,6-二氯甲苯由于甲基邻位有两个较大位阻且较强吸电子的氯原子影响, 甲基活性较低, 较难发生氨氧化反 应, 原料转化率和产品收率均较低. 本课题组一直致力于发展高活性和选择性的氨氧化催化剂以及有效的策略实现甲基 芳烃高效转化为芳香腈, 我们曾以硅胶负载的钒磷氧化物 $\left(\mathrm{VPO} / \mathrm{SiO}_{2}\right)$ 和钒铬氧化物 $\left(\mathrm{VCrO} / \mathrm{SiO}_{2}\right)$ 为催化剂, 成功实现了 2,6二氯甲苯氨氧化反应制备2,6-二氯苯腈.

钒铬复合氧化物( $\mathrm{VCrO})$ 具有广泛的应用, 可用于多相催化、气体传感、能量储存等领域. VCrO通常通过高温固相反 应制备, 然而一般得到的是混合相, 产品形态和颗粒大小也不能很好控制; 当用于氧化或氨氧化反应时, 需要较高的反应 温度, 原料也容易发生过度氧化, 导致积碳及活性降低.

我们以 $\mathrm{V}_{2} \mathrm{O}_{5}$ 和 $\mathrm{CrO}_{3}$ 为原料, 在醇或者醇水溶液中于 $180^{\circ} \mathrm{C}$ 进行溶剂热反应制备了无定形的 $\mathrm{VCrO}$ 前驱体, 然后将前驱 体在不同温度下氮气气氛中炦烧, 产品通过粉末 $X$ 射线衍射、透射电镜和 X射线光电子能谱等进行表征. 当以甲醇或甲醇水 溶液为溶剂热反应介质, 并且前驱体 $700^{\circ} \mathrm{C}$ 进行煅烧后, 产品为纯的正交晶系 $\mathrm{CrVO}_{4}$ 纳米晶相; 当以甲醇为溶剂时, $\mathrm{CrVO}_{4}$ 晶相的尺寸大约为 $500 \mathrm{~nm}$; 而改为甲醇水溶液为溶剂时, 产品尺寸急剧减小到 $50 \mathrm{~nm}$ 以下, 而且通过改变甲醇和水的体积 比分别为 $10: 1,5: 1,1: 1$ 和1:5时, $\mathrm{CrVO}_{4}$ 纳米晶相的尺寸从 $50 \mathrm{~nm}$ 逐渐减小到 30,20 和 $10 \mathrm{~nm}$, 能够进行有效调控. 据我们所知, 这是首次合成纯的 $\mathrm{CrVO}_{4}$ 纳米晶相. 我们以该纳米 $\mathrm{CrVO}_{4}$ 为催化剂催化2,6-二氯甲苯氨氧化反应制备 2,6-二氯苯腈, 在 $335^{\circ} \mathrm{C}$ 的相对较低温度下反应, 原料转化率为 $84 \%$, 产品收率为 $75 \%$; 进一步升高温度到 $390{ }^{\circ} \mathrm{C}$, 原料转化率为 $99 \%$, 产品收 率可达 $81 \%$. 在所有已报道的二元复合氧化物催化剂中, 纳米 $\mathrm{CrVO}_{4}$ 显示了最高的催化活性, 主要归功于它较小的粒子尺 寸、较大的表面积和更多暴露的活性中心.
\end{abstract}

关键词: $\mathrm{CrVO}_{4}$; 纳米晶相材料; 复合氧化物; 溶剂热合成; 氨氧化

收稿日期: 2018-04-12. 接受日期: 2018-06-01. 出版日期: 2018-11-05.

*通讯联系人. 电话/传真: (027)67842752; 电子信箱: xiegy@scuec.edu.cn

†共同第一作者.

基金来源：国家自然科学基金(21172269); 湖北省创新群体项目(2018CFA023); 江汉大学光电化学材料与器件教育部重点实验室 开放基金(JDGD-201809).

本文的电子版全文由Elsevier出版社在ScienceDirect上出版(http://www.sciencedirect.com/science/journal/18722067). 